\title{
Circuit-X: Circuit Analysis meets the X Files
}

\author{
Glen E. Archer, Leonard J. Bohmann \\ Michigan Technological University
}

Circuits education is one of the cornerstones in educating an electrical engineer. As Davis points out ${ }^{1}$ there is a need to relate analysis skills to the real world. Other authors have done this by incorporating design into the circuits $\mathrm{lab}^{2,3,4}$ or by integrating computer tools into the lab ${ }^{5,6}$. An additional strategy is to challenge the students with a circuit identification task, one where they have to design test procedures and from the results synthesize the unknown circuit. Most lab experiences consist of opportunities to build circuits from homework problems and verify already well established electrical principles. From a pedagogical point of view this represents the path of least resistance. Little effort is required to create, deliver and administer lab programs that follow such a paradigm. There is small risk that even marginally qualified teaching assistants will be unable to successfully supervise students thus engaged. Ohm's law is known, KVL and $\mathrm{KCL}$ are known, the measurements are predetermined and the outcome foreordained. With all the answers known in advance, it's difficult to imagine how anyone would expect any learning to take place. Circuit X is designed to challenge students' understanding of circuits, their reasoning skills, their mastery of test equipment operation, and their ability to convincingly present an argument.

The Circuit X lab experience occurs in the first few weeks of the first 3rd year lab. During the first week of the project each student team is given one of fourteen unknown circuits to analyze. The circuit is contained in a small black box (Figure 1.) that is riveted closed. The boxes and circuits were fabricated by the ECE department machine shop and electronic technicians. Each box contains a unique first or second order passive circuit that must be analyzed by the students to determine the circuit topology and component values. The graduate teaching assistants have access to the master record of which box contain which circuit. The boxes are numbered for easy identification. Electrical access to the interior circuit is limited to four banana style jacks arranged in a square on one surface of the box. Connector spacing makes it convenient to use banana-BNC adaptors along the sides of the square but not along the diagonals. The terminals are numbered for common reference.

"Proceedings of the 2005 American Society for Engineering Education Annual Conference \& Exposition Copyright (C) 2005, American Society for Engineering Education” 


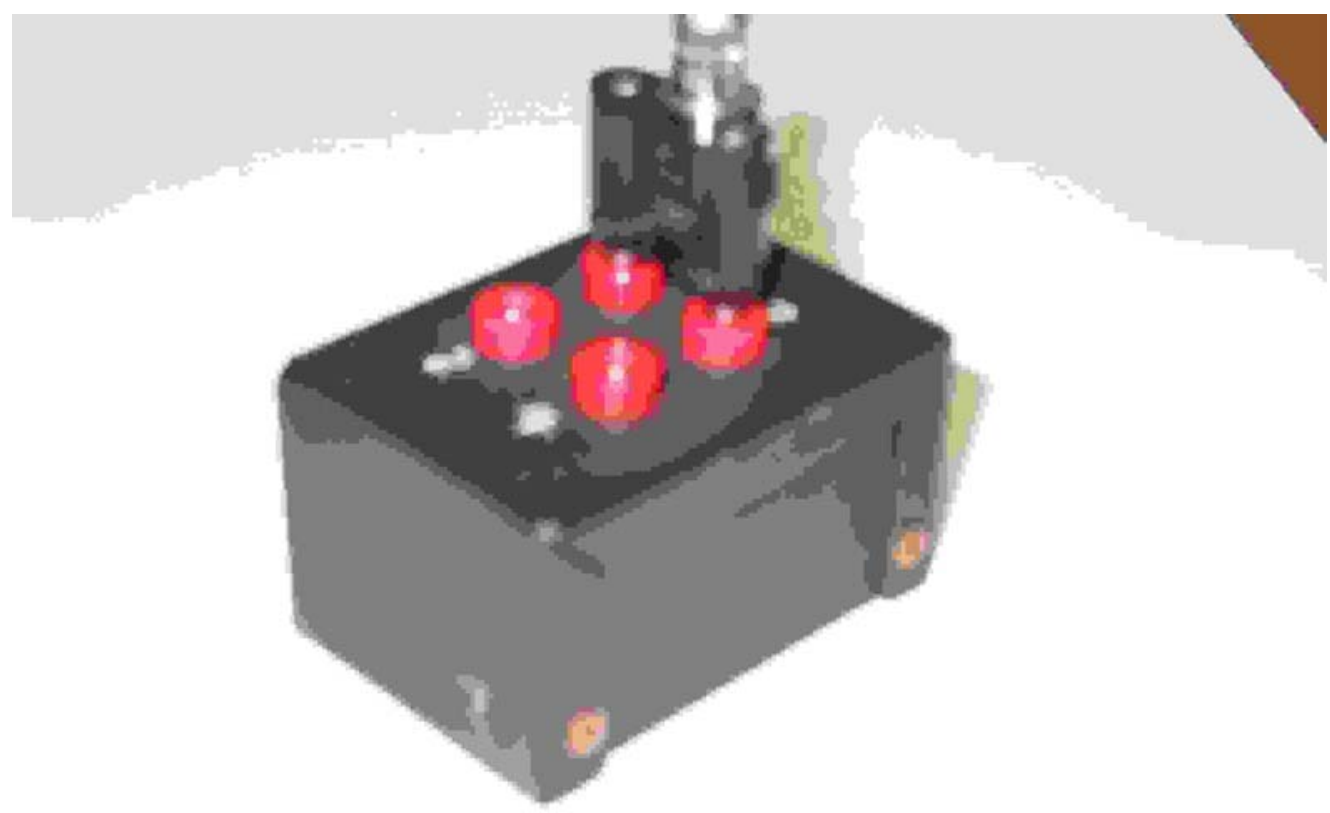

Figure 1. Photograph of a Circuit X student box.

The story line that creates a hook for the student's interest is that the black boxes contain "alien technology" and may hold the key to a source of cheap energy. The complete text of the student instructions follows.

\section{Circuit $X$}

Michigan Tech has received an urgent request from the global scientific community. The United Federation of Scientists (UFOS) has acquired several samples of suspected alien technology. Each device is enclosed in a sealed metal container with four electrical connectors. The scientific community is very curious about the device characteristics because they are reputed to hold the keys to a global source of cheap energy.

Information received with the devices leads the UFOS community that they are electrical circuits composed of elements similar to what terrestrial scientists call "passive components."

Your task is twofold:

- Prepare and submit a test proposal that fully describes a set of tests that will reveal the exact nature of the circuit within the alien device.

- After your test proposal is approved, conduct your examination and report your findings in the form of a schematic drawing of the alien circuit.

First, you will work in teams to design a set of tests that will enable you to precisely describe the circuits contained in the alien devices. This Test Proposal must be submitted to your TA and approved BEFORE you conduct your tests. Please include a

"Proceedings of the 2005 American Society for Engineering Education Annual Conference \& Exposition Copyright (C) 2005, American Society for Engineering Education" 
detailed, step-by-step description of all proposed tests including equipment required, connections to be made to the device under test, signal inputs, and the expected results of the test. Also, include decision trees, drawings and schematics as necessary to fully illustrate your test proposal. Each team will submit a test proposal to their TA not later than one-week after the device is received. You will not be allowed to proceed to the next step in the process until you have received an approved Test Proposal from your TA. This may take several attempts. Your TA will provide you with feedback to guide your efforts. Safety Note: The first attempt to open a container for examination resulted in a highly energetic response that caused the complete destruction of the lab, the scientists and a local village. DO NOT attempt to open the case on your test device. All examinations of these devices must be performed without exposing the contents.

Restrictions: Do not apply more than $5 \mathrm{~V} D C$ to any terminal of the device. Do not remove the suspected alien technology from EERC room 619.

After you receive your approved Test Proposal from your TA, conduct the tests according to the procedures developed in the Test Proposal. Report your conclusions about the exact nature of the circuit, including circuit topology and component characteristics in standard lab report format prescribed by department policy. Include drawings, schematics and an assessment of your confidence in the precision of your findings. Your report will be deliverable one week after receipt of your approved Test Proposal. Be prepared to present your findings (3-5 minutes) to a panel of distinguished researchers one week after your report is delivered. All reports will be completed by Friday of Week 4. See the attached process diagram (Fig. 1) for more information.

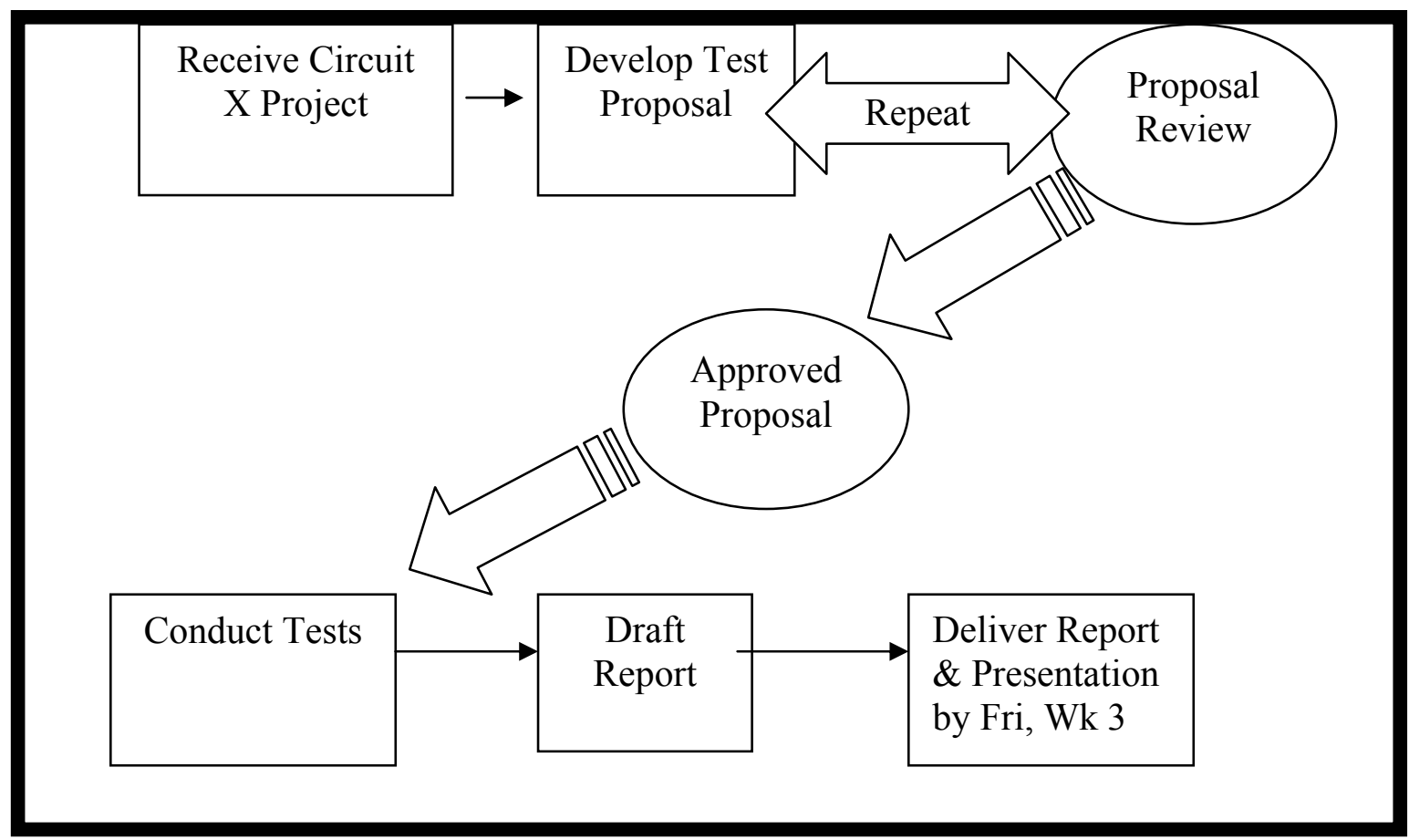

Figure 2. Circuit X Instructions

"Proceedings of the 2005 American Society for Engineering Education Annual Conference \& Exposition Copyright (C) 2005, American Society for Engineering Education" 
Three two hour lab sessions are allocated for the Circuit X project. During the first lab session the student teams receive their test sample and instructions and begin to draft their test plan. No measurements are allowed during this introductory session. Each team has the usual bench test equipment available to them, including multimeters, power supplies, function generators and an oscilloscope. Each item of test equipment is connected via IEEE 488 bus to a desktop computer running Labview software. The only item of test equipment they are restricted from using is the LRC meter.

The teaching assistant is available to answer questions and offer suggestions for the remainder of the lab period. The object of the test plan is to encourage the student teams to determine what information they will need in order to characterize the circuit and exactly how they will use the test equipment available to them in order to extract it. The teaching assistants are coached to reject test plans that do not provide sufficient detail. Sufficient detail is defined here to mean: enough detail for someone else to execute the plan and arrive at an inevitable conclusion. Each step must define what they will do, how they will do it, what data will be acquired, and how that data leads to information about the circuit. Most teams will have a rudimentary test plan prepared by the end of the period. Most test plans go through multiple iterations before they receive approval from the "Test Director," their TA. This iterative process typically takes place via email over the following week, outside the lab. The intent is to require the student teams to be disciplined and thorough in their investigation and avoid time wasting random experimentation. All teams are given two weeks to finalize their test plans and have them approved in time for the next scheduled Circuit X lab meeting.

During the execution phase of Circuit X each team has the opportunity to explore just how effective their test plan was as they carry out the process they created. This does not always go smoothly. Students regularly observe data that do not fit their preconceptions. Flexible teams regroup and reassess the underlying assumptions that led them to a particular step or conclusion and move forward. Less robust teams are forced by circumstances to reevaluate not only their test plan but, in many cases, their basic understanding of circuits and test equipment operation.

The lack of certainty posed by the unknown circuit causes a number of secondary effects. First, the teams are forced to examine and in most cases strengthen their understanding of basic circuit theory in order to be able to determine what data will be relevant. Second, they must develop a deeper understanding of the operation, abilities and limitations of their test equipment in order to be able to tell the difference between data that doesn't fit their model and bad measurement technique. The TA's are cued to watch for and guide the frustration that inevitably results from the conflict between expectation and reality. It is in this sometimes painful process of question and answer that deeper understandings can develop. For example, many students will immediately turn to their handy multimeter for initial measurements. Puzzled expressions occur when ohmmeters are placed in parallel with capacitors and inductors. The questions that follow lead students to discover how common meters actually measure resistance. Ultimately they are brought to the ability to actually apply what they have learned in the classroom to solve a problem.

The final phase of the project is the written report and oral presentation of results. Each team produces a written report to document their work. In addition they deliver a 5 minute presentation to the class. Both these forms of communication are vital to the successful student and ultimately to the practicing engineer. The teaching assistant challenges each team with questions that revolve are a central theme, "What's the answer? Is that the only answer? How do you know?" In every case the student teams must demonstrate the ability to present their argument convincingly. Both the report and the presentation are graded using a common rubric

"Proceedings of the 2005 American Society for Engineering Education Annual Conference \& Exposition Copyright (C) 2005, American Society for Engineering Education” 
in order to ensure consistency between sections supervised by different teach assistants. These rubrics are included as appendices. It is worthwhile to note that the "correct" answer contributes at most 10 points of the total points available for the project.

A prerequisite exam is administered to all students in the Circuits and Analysis lab during the first week of the semester. The exam is designed to assess mastery basic circuit analysis skills and knowledge. The exam includes questions requiring knowledge of Wheatstone bridge circuits, nodal analysis of circuits with dependent and independent sources, and a first order RL circuit. The mean score on 36 exams was 10.6 out of a possible 20 points, with a standard deviation of 4.5. One question dealt specifically with a first order RL circuit. Only two individuals received full credit for the question, the mean score for that question was 0.73 out of a possible 5 points. After completion of the Circuit X lab experience, the sections were invited to participate in a post test to assess any change of state. Three individuals volunteered and were given a single question related to first order circuits. All three volunteers were able to correctly answer questions regarding frequency response, transfer function, and time constant for a first order RC circuit. Clearly more participation in the post test would have been desirable but even this small sample points toward a successful transfer of information.

Its easy for both the students and the teaching assistants to get wrapped around the circuit. In fact the circuit is just a small part of the overall experience. The substance of this lab rests on three foundations: Discovery, Design, and Delivery. First the student teams must design an effective test plan that will lead them from the known, i.e. circuit theory, through the unknown, and back again. This design process challenges their reasoning skills as well as their understanding of circuits and equipment. What do I need to observe?. How can I measure it? Is this the right tool? What does my observation tell me about the item under test? And always, "What went wrong?" The discovery part happens when they put their plan into action. They discover that they don't understand circuits as well as they thought they did. Six papers were drawn from a pool of approximately 60. All six reported that at least one step in their test plan was not performed because one or more assumptions conflicted with observations in the execution phase. They discover that they need a deeper understanding of how their measurement equipment works or how to interpret what it tells them. All six reported data that did not fit their expectations and described their efforts to understand what they observed. Mostly they persevere until they develop this deeper understanding that enables them to deliver on the project. Four of the six teams were able to correctly determine the topology and the element values despite the challenges they encountered. Every team strengthened their knowledge of circuits, and deepened their understanding of equipment operation by meeting this challenge, overcoming it, and then telling the world about their experience.

Leonard J. Bohmann is an Associate Professor of Electrical Engineering at Michigan Tech where he has worked since 1989. He received his Ph.D. (1989) and MSEE (1985) from the University of Wisconsin Madison and his BEE (1983) degree from the University of Dayton. Dr. Bohmann is a member ASEE and IEEE and is a Licensed Professional Engineer in the State of Michigan.

Glen E. Archer, Maj USAF (ret) is a Lecturer in Electrical Engineering at Michigan Tech where he has worked since 1999. He received his MS (1993) from Webster University and his BSEE (1986) degree from Texas Tech. Major Archer is a member of ASEE.

"Proceedings of the 2005 American Society for Engineering Education Annual Conference \& Exposition Copyright (C) 2005, American Society for Engineering Education” 


\section{References}

1. Some fundamental topics in introductory circuit analysis: a critique;

Davis, A.M.; Education, IEEE Transactions on , Volume: 43 , Issue: 3 , Aug. 2000

Pages:330 335

2. A new design-oriented laboratory for the introductory circuits core course at Penn State University; Mayer, T.S.; Medunick, J.R.; Chunyu Zhang; Jackson, T.N.; Frontiers in Education Conference, 1997. 27th Annual Conference. 'Teaching and Learning in an Era of Change'.

Proceedings., Volume: 1, 5-8 Nov. 1997 Pages:506 - 510 vol.1

3. Laboratories for introductory circuits and electronics; Takach, M.D.; Heeren, R.G.; Frontiers in Education Conference, 1995. Proceedings., 1995 , Volume: 2 , 1-4 Nov. 1995 Pages:4c2.5 $4 \mathrm{c} 2.9 \mathrm{vol} .2$

4. A Design Based Introduction to Electrical Engineering; Paskusz, G.F.;

Frontiers in Education Conference, 1998. FIE '98. 28th Annual, Volume: 2, November 4-7, 1998

Pages:955 - 957 vol.2

5. Teaching EE circuits I lab with Labview; Nunnally, C.E.;

Frontiers in Education Conference, 1996. FIE '96. 26th Annual Conference., Proceedings of, Volume: 2 , 6-9 Nov. 1996; Pages:871 - 873 vol.2

6. A paperless circuits laboratory: vision and reality; Lightner, M.; Avery, J.; Frontiers in Education Conference, 1996. FIE '96. 26th Annual Conference., Proceedings of , Volume: 3 , 6-9 Nov. 1996 Pages:1186 - 1190 vol.3 
PRESENTATION GRADE SHEET

\begin{tabular}{|c|c|c|c|c|c|c|c|c|}
\hline \multicolumn{2}{|c|}{ NAME OF STUDENT } & \multicolumn{2}{|c|}{ TOPIC } & \multicolumn{5}{|c|}{ DATE } \\
\hline & Unsatisfactory & Satisfactory & Outstanding & $\mathbf{U}$ & $\mathbf{L}$ & $\mathbf{S}$ & $\mathbf{H}$ & $\mathbf{O}$ \\
\hline \multicolumn{9}{|c|}{ ORGANIZATION } \\
\hline $\begin{array}{l}\text { INTRODUCTION } \\
\text { (ATTENTION } \\
\text { STEP \& } \\
\text { OVERVIEW) }\end{array}$ & $\begin{array}{l}\text { Emotional; failed to introduce } \\
\text { self/subject; vague/laundry listed. }\end{array}$ & $\begin{array}{l}\text { Appropriate; claimed audience's } \\
\text { attention/highlighted main points. }\end{array}$ & $\begin{array}{l}\text { Stimulating; original; clear/well } \\
\text { expanded; prepared listeners fully. }\end{array}$ & 0 & $1-3$ & $4-6$ & $\begin{array}{l}7- \\
9\end{array}$ & $\begin{array}{l}1 \\
0\end{array}$ \\
\hline $\begin{array}{l}\text { SUPPORT } \\
\text { (VISUAL \& } \\
\text { VERBAL) }\end{array}$ & $\begin{array}{l}\text { Inadequate development/ } \\
\text { errors/sloppy; awkwardly used, } \\
\text { inadequate sources. }\end{array}$ & $\begin{array}{l}\text { Adequate development; credible } \\
\text { facts/supported or illustrated ideas, } \\
\text { cited sources. }\end{array}$ & $\begin{array}{l}\text { Comprehensive development/ } \\
\text { stimulating; well timed; skillfully } \\
\text { used, incorporated sources } \\
\text { throughout. }\end{array}$ & & & & & \\
\hline $\begin{array}{l}\text { ORGANIZATION } \\
\text { (LOGIC \& } \\
\text { TRANSITIONS) }\end{array}$ & $\begin{array}{l}\text { Vague; lacked balance/mechanical } \\
\text { transitions throughout. }\end{array}$ & $\begin{array}{l}\text { Main ideas related to purpose/each } \\
\text { other/used some creative } \\
\text { transitions. }\end{array}$ & $\begin{array}{l}\text { Skillfully led audience/creatively } \\
\text { related previous points to new } \\
\text { points. }\end{array}$ & & & & & \\
\hline $\begin{array}{l}\text { CONCLUSION } \\
\text { (SUMMARY \& } \\
\text { CLOSURE) }\end{array}$ & $\begin{array}{l}\text { Incomplete; laundry listed/abrupt; } \\
\text { no sense of finality. }\end{array}$ & $\begin{array}{l}\text { Reviewed highlights of main } \\
\text { points/ definite; appropriately tied } \\
\text { to subject. }\end{array}$ & $\begin{array}{l}\text { A synthesis; fostered retention of } \\
\text { ideas/positive impact creative. }\end{array}$ & & & & & \\
\hline \multicolumn{9}{|c|}{ DELIVERY } \\
\hline $\begin{array}{l}\text { VERBAL } \\
\text { EXPRESSION }\end{array}$ & $\begin{array}{l}\text { Articulation problems; incorrect } \\
\text { grammar/pronunciation; vocalized } \\
\text { pauses; poorly worded; monotone; } \\
\text { too soft/loud; too slow/fast; } \\
\text { artificial; lacked confidence. }\end{array}$ & $\begin{array}{l}\text { Not distracting; natural force, } \\
\text { pitch, rate, and emphasis; positive. }\end{array}$ & $\begin{array}{l}\text { Exceptional articulation, } \\
\text { pronunciation, grammar; precise } \\
\text { word choice; dynamic; } \\
\text { spontaneous; conversational; } \\
\text { varied. }\end{array}$ & & & & & \\
\hline MOVEMENT & $\begin{array}{l}\text { Static movement, pacing, } \\
\text { distracting, hindered } \\
\text { communication, nervous. }\end{array}$ & $\begin{array}{l}\text { Varied movement, usually } \\
\text { purposeful. }\end{array}$ & $\begin{array}{l}\text { Purposeful movement, } \\
\text { comfortable, confident, enhanced } \\
\text { presentation. }\end{array}$ & & & & & \\
\hline GESTURES & $\begin{array}{l}\text { Mechanical gestures, mechanical, } \\
\text { exaggerated, poorly timed, } \\
\text { distracting, nervous. }\end{array}$ & $\begin{array}{l}\text { Appropriate gestures, aided } \\
\text { communication. }\end{array}$ & $\begin{array}{l}\text { Gestures enhanced presentation, } \\
\text { spontaneous, natural, consistently } \\
\text { reinforced meaning. }\end{array}$ & & & & & \\
\hline EYE CONTACT & $\begin{array}{l}\text { Missing or partial eye contact; } \\
\text { focused on visual-aids or notes. }\end{array}$ & $\begin{array}{l}\text { Included most listeners; acceptable } \\
\text { reference to notes. }\end{array}$ & $\begin{array}{l}\text { Direct eye contact; random; rarely } \\
\text { used notes, sought feedback. }\end{array}$ & & & & & \\
\hline
\end{tabular}


Circle the box that best describes the lab report. Assign points on the right and total at the bottom.

\begin{tabular}{|c|c|c|c|c|}
\hline Attribute & 0-2 Unacceptable & $\begin{array}{l}\text { 3-5 Below } \\
\text { Expectations }\end{array}$ & $\begin{array}{l}\text { 6-8 Meets } \\
\text { Expectations }\end{array}$ & $\begin{array}{l}\text { 9-10 Exceeds } \\
\text { Expectations }\end{array}$ \\
\hline \multicolumn{5}{|l|}{$\begin{array}{l}\text { Report } \\
\text { Mechanics }\end{array}$} \\
\hline Organization & $\begin{array}{l}\text { Inappropriate content } \\
\text { in most sections of } \\
\text { report }\end{array}$ & $\begin{array}{l}\text { Some inappropriate } \\
\text { content in some } \\
\text { sections of report }\end{array}$ & $\begin{array}{l}\text { Content appropriate } \\
\text { in all sections of } \\
\text { report }\end{array}$ & $\begin{array}{l}\text { Unique organization } \\
\text { enhances readability } \\
\text { and/or } \\
\text { understandability of } \\
\text { report }\end{array}$ \\
\hline Format & $\begin{array}{l}\text { Tables and figures } \\
\text { can not be } \\
\text { read/understood, } \\
\text { fonts difficult to read, } \\
\text { so many format } \\
\text { errors as to make the } \\
\text { report useless }\end{array}$ & $\begin{array}{l}\text { Some portions are } \\
\text { sloppy and difficult } \\
\text { to read, some format } \\
\text { errors }\end{array}$ & $\begin{array}{l}\text { Text, tables, figures } \\
\text { are readable and } \\
\text { understandable. }\end{array}$ & $\begin{array}{l}\text { Text, tables, figures } \\
\text { so clear and } \\
\text { understandable as to } \\
\text { enhance the report's } \\
\text { impact, unique } \\
\text { format enhances } \\
\text { report's impact }\end{array}$ \\
\hline $\begin{array}{l}\text { Grammar, } \\
\text { Punctuation, Spelling }\end{array}$ & $\begin{array}{l}\text { Excessive spelling, } \\
\text { grammar, and } \\
\text { punctuation errors }\end{array}$ & $\begin{array}{l}\text { Some spelling, } \\
\text { grammar, and } \\
\text { punctuation errors }\end{array}$ & $\begin{array}{l}\text { Only a few spelling, } \\
\text { grammar, and } \\
\text { punctuation errors }\end{array}$ & $\begin{array}{l}\text { Completely free of } \\
\text { spelling, grammar, } \\
\text { and punctuation } \\
\text { errors }\end{array}$ \\
\hline Length & $\begin{array}{l}\text { Far too long or too } \\
\text { short }\end{array}$ & Too long or too short & $\begin{array}{l}\text { Appropriate report } \\
\text { length }\end{array}$ & \\
\hline \multicolumn{5}{|l|}{ Content } \\
\hline Abstract & $\begin{array}{l}\text { Problem not stated, } \\
\text { conclusion not } \\
\text { summarized, process } \\
\text { statements only }\end{array}$ & $\begin{array}{l}\text { Problem somewhat } \\
\text { stated, significant } \\
\text { results not included }\end{array}$ & $\begin{array}{l}\text { Problem clearly } \\
\text { stated, key results or } \\
\text { conclusion stated } \\
\text { clearly }\end{array}$ & $\begin{array}{l}\text { So clear and } \\
\text { complete as to } \\
\text { enhance the impact } \\
\text { of the report }\end{array}$ \\
\hline Introduction & $\begin{array}{l}\text { Problem not stated, } \\
\text { constraints or } \\
\text { assumptions not } \\
\text { explained, contains } \\
\text { results/conclusions }\end{array}$ & $\begin{array}{l}\text { Problem stated } \\
\text { poorly, limited } \\
\text { discussion of } \\
\text { constraints, } \\
\text { assumptions }\end{array}$ & $\begin{array}{l}\text { Problem clearly } \\
\text { stated, impact of } \\
\text { constraints and } \\
\text { assumptions clearly } \\
\text { discussed }\end{array}$ & $\begin{array}{l}\text { So clear and } \\
\text { complete as to } \\
\text { enhance impact of } \\
\text { report }\end{array}$ \\
\hline $\begin{array}{l}\text { Discussion- } \\
\text { Quantitative } \\
\text { Analysis-- }\end{array}$ & $\begin{array}{l}\text { No apparent } \\
\text { understanding of lab } \\
\text { tasks, no quantitative } \\
\text { support provided }\end{array}$ & $\begin{array}{l}\text { Poor understanding } \\
\text { of lab tasks, poor } \\
\text { quantitative support, }\end{array}$ & $\begin{array}{l}\text { Lab tasks clearly } \\
\text { understood and } \\
\text { discussed, solid } \\
\text { quantitative support, }\end{array}$ & $\begin{array}{l}\text { Discussion clearly } \\
\text { reveals insight and } \\
\text { understanding } \\
\text { beyond level } \\
\text { expected }\end{array}$ \\
\hline $\begin{array}{l}\text { Conclusion_-What } \\
\text { did you learn }\end{array}$ & Omitted & Weak & Clear & $\begin{array}{l}\text { Conclusion clearly } \\
\text { reveals insight and } \\
\text { understanding } \\
\text { beyond level } \\
\text { expected }\end{array}$ \\
\hline Questions & $\begin{array}{l}\text { Did not address } \\
\text { questions posed in } \\
\text { lab materials }\end{array}$ & $\begin{array}{l}\text { Some questions } \\
\text { correctly answered }\end{array}$ & $\begin{array}{l}\text { All questions } \\
\text { correctly answered }\end{array}$ & \\
\hline
\end{tabular}


"Proceedings of the 2005 American Society for Engineering Education Annual Conference \& Exposition Copyright (C) 2005, American Society for Engineering Education” 